\title{
Deportees in Inadmissible Facility Have Right to Apply for Asylum Abdi and Another v Minister of Home Affairs and Others 20113 SA 37 (SCA)
}

\author{
Jean Chrysostome Kanamugire \\ Lecturer, Faculty of Law, North-West University \\ Email: jean.kanamugire@nwu.ac.za \\ Alternative email: kajec1@yahoo.co.uk
}

Shaida Alli

Lecturer, Faculty of Law, University of KwaZulu-Natal

Doi:10.5901/mjss.2013.v4n13p171

\begin{abstract}
Since 1994, South Africa has become host to refugees from African continent and overseas. Refugees flee their countries for various reasons, including persecution and insecurity. Under international law and South African law, it is unlawful to deport a person who wishes to claim for asylum. Deporting asylum seekers violates the principle of non-refoulement, which is the most fundamental principle of refugee law. This principle guarantees a person's right not to be forcibly returned to a place where the person would face a threat of persecution or a real risk of torture or cruel, inhuman, degrading treatment or punishment. Deportees in inadmissible facility have right to apply for asylum in the Republic of South Africa. They are located in an area that is under the sovereignty of the RSA. Therefore, the Bill of Rights in the Constitution, international conventions and municipal laws governing refugees and asylum seekers apply to such individuals. Once there is an indication to apply for asylum, the officials of Home Affairs have a duty to assist the concerned person to file such application at a Refugee Reception Office. Government officials, who intentionally fail to perform their tasks as provided by the statutes and cause hardship to persons who expect their assistance, should be ordered to pay punitive costs. This will encourage government officials to perform their duties adequately without unreasonable delay.
\end{abstract}

Keywords: Asylum seekers; refugees; non-refoulement; immigration detention; deportees.

\section{Introduction}

Since South Africa's transition to full democracy in 1994, it has become host to refugees from across the African Continent and overseas. These refugees have fled their countries for various reasons, including seeking protection and prosperity. Under South African and international law, it is unlawful to deport anyone who wishes to claim asylum. The South African Refugees Act 130 of 1998 has built-in the principle of International and Regional Conventions pertaining to the rights and protection of refugees. Deporting asylum seekers violates the most fundamental principle of refugee law, the principle of non-refoulement, which guarantees a person's right not to be forcibly returned to a place where the person would face a threat of persecution or a real risk of torture or cruel, inhuman, or degrading treatment or punishment (Refugees Act130 of 130, s 21 (4) and Regulation 2 (2) of the Refugee Regulation). It is against this backdrop that the writers analyse the decision of the Supreme Court of Appeals in Abdi and Another v Minister of Home Affairs and Others 2011 (5) BCLR 529 (SCA), 20113 SA 37 (SCA) (hereinafter referred to as the Abdi case).

In Abdi case, the court ordered the release of the deportees who were in transit in inadmissible facility at the OR Tambo International Airport from Namibia to Somalia via South Africa. The appellants were held in inadmissible facility at the OR Tambo International Airport. They were respectively asylum seeker and refugee in South Africa before they left and went to Namibia where they fought they could be resettled to a developed state like Canada. Their release creates a precedent that South Africa cannot be involved in a deportation of a refugee or asylum seeker to a place where they may be persecuted.

\section{The facts}

The appellants were the citizens of Somalia. They fled Somalia and travelled to the Republic of South Africa (RSA) to 
seek for asylum. First appellant was a registered asylum seeker. Second appellant was a recognised refugee. However, because of their fears of xenophobia in the RSA, they left for Namibia after being told that the officers of the United Nations High Commissioner for Refugees (UNHCR) in Namibia might be able to arrange for their admission to a country like Canada where they could further their education. They left South Africa to Namibia without informing the authorities. They were then arrested and deported from Namibia as illegal aliens. Appellants were flown by Air Namibia to Johannesburg in order to deport them. The intention was to transport them to Mogadishu. Appellant were held in the inadmissible facility at the OR Tambo International Airport. Subsequently, they were told that they were to be put on an Air Kenya flight to Mogadishu via Nairobi. They feared that their lives would be in danger if they were to be forced to return to Somalia. Pamela Msizi (Msizi), a protection officer from the UNHCR, attempted to assist them.

Msizi contacted and engaged with the Department of Home Affairs. The officers tasked to deal with appellants' case refused to permit their entry into the RSA adopting the stance that appellants were Namibian deportees and that the South African authorities had no jurisdiction to interfere with another state's deportation order. Msizi then initiated urgent proceedings in the North Gauteng High Court aimed at interdicting the first and second respondent from forcing appellants to board a flight to Somalia, and obtaining a mandamus against respondents to facilitate appellants' readmission to the RSA. The application to release the appellants was refused but the court granted leave to appeal to the Supreme Court of Appeals (SCA).

\section{Respondents' Argument}

Respondents' main contention was that they lacked jurisdiction to consider or interfere with the deportation order of the appellants because they were not legally in the RSA while being detained at the Inadmissible Facility. The Respondents argued that the appellants were Namibian deportees making them the responsibility of Namibia. The respondents' alternate argument was that, as deportees of another country, the appellants had no right to invoke the protection of the Refugees Act 130 of 1998. An additional argument brought by the respondents was that the department had had no record of the appellants and even if they did, the appellants had waived their right to be considered as refugees or asylum seekers when they left RSA without the necessary consent from the Minister or any other authority.

\section{Appellants' Argument}

The respondent's allegation that the department has no record of the appellants was refuted in the replying affidavits. The first appellant's status as asylum seeker was recognised by his file, the second appellant's status as refugee was established from his permit. In the High Court, it was found that the applicants had not established their status as recognised refugee and asylum seeker and that South African courts lacked jurisdiction to interfere with Namibian deportation order. The application was dismissed. Leave to appeal to the SCA was granted by the High Court. The applicants were allowed to remain in the facility pending the appeal.

\section{The decision}

The Supreme Court of Appeals made an order directing the immediate release of appellants from detention in the Inadmissible Facility at OR Tambo International Airport. It was declared that the first appellant was entitled to remain in the RSA until a decision had been made on his application for asylum and, where applicable, until he had had an opportunity to exhaust his rights of review or appeal in terms of chapter 2 of the Refugees Act 130 of 1998 and the Promotion of Administrative Justice Act 3 of 2000. It was also declared that the second appellant was entitled to remain in the RSA in accordance with his status as a refugee. First and second respondents were directed to issue each of the first and second appellants with an asylum transit permit in terms of section 23 of the Immigration Act 13 of 2002. Such permits would remain valid for 14 days, during which period the first and second appellants would reside at a certain address, or such other address as was provided to them. The first and second respondents were ordered to pay the costs of the application (paras 1 and 38).

\section{Comments}

It is submitted that this decision is welcome for the following reasons or respects:

- Deportees on the port of entry or in inadmissible facility have a right to apply for asylum. 
- It respects the international conventions and municipal laws governing refugees.

- It emphasizes sovereignty of the state.

- It discusses punitive costs for officials who intentionally disregard their duties.

\subsection{Deportees have a right to apply for asylum}

The respondents argued that they were not responsible for the appellants as they were being deported by another country. They were in fact the responsibility of Air Namibia, on whose flight they had been brought to South Africa. They relied on the Chicago Convention on International Aviation, which was said to impose the duty upon the carrier [para 15]. This convention has been amended in 2005 to include a provision that facilitates individuals at the port of entry to apply for asylum. In addition, this convention has been incorporated in South African law by Civil Aviation Act 13 of 2009 (para 25). The Home Affairs' officials have a duty to ensure that intending applicants for refugee status are given every reasonable opportunity to lodge an application with the relevant Refugee Reception Office (para 22; Bula \& Others $v$ Minister of Home Affairs \& Others (589/11) [2011] ZASCA 209 para 77). This applies to every asylum seekers whether they are inside the country or held in inadmissible facilities.

The respondents also argued or submitted that while being detained at the inadmissible facility, the appellants were not in law in South Africa and the South African authorities and courts had no jurisdiction over them. They were held pending their return to Namibia and were thus not being deported. Their status in South Africa was irrelevant to their fate (para 15). The argument that individuals who are being held in inadmissible facility at a port of entry into the RSA are beyond the courts' jurisdiction was answered in the case of Lawyers for Human Rights and Another v Minister of Home Affairs and Another 20044 SA 125 (CC), 20077 BCLR 775 (CC). In this case, the government contended that the Bill of Rights does not accord protection to foreign nationals at port of entry who have not yet been allowed formally to enter the country. Yacoob J held that sections 12 and 35 (2) in the Bill of Rights 'are integral to the value of human dignity, equality, and freedom that are fundamental to our constitutional order. The denial of these rights to human beings who are physically inside the country at sea - or airports merely because they have not entered South Africa formally would constitute a negation of the value underlying our Constitution. It could hardly be suggested that persons who are being unlawfully detained on a ship in South African waters cannot turn to South African courts for protection, or that a person who commits murder on board a ship in South African waters is not liable to prosecution in a South African court' (para 20, Lawyers for Human Rights and Another v Minister of Home Affairs and Another (supra) para 26). Passengers on an international flight landing in South Africa are subject to the jurisdiction of South African courts (see Nkondo v Minister of Police and Another 19802 SA 894 (0), 19804 All SA 67 (O)). In this regard, courts can ascertain whether international laws as well as municipal laws have been complied with.

\subsection{International conventions and municipal laws governing refugees}

The respondents' submission is not only incompatible with the provisions of the 1951 United Nations Convention on the Status of Refugees and its 1967 protocol as well as the 1969 Convention Governing the Specific Aspects of Refugee problems in Africa, but also with the provisions of the Refugees Act 130 of 1998, section 6 of which provides for it to be applied with due regard to the provisions of the UN Convention and its protocol as well as the 1969 OAU Convention. The Refugees Act also provides for the admission of foreigners who find themselves in distressed circumstances owing to the condition enumerated in sections 2 and 3. (Para 22; section 2 of the Refugees Act deals with general prohibition of refusal of entry, expulsion, extradition, or return to the country in certain circumstances, while section 3 provides for refugee status). Refugees Act has incorporated the 1951 UN Convention and the OAU Convention of 1969 into South African municipal laws. Their words potently prohibit the prevention of access to the RSA of any person who has been forced to flee the country of his or her birth because of any of the circumstances that qualify a person for a refugee status (para 22; Bula \& Others (supra) para 61).

Individuals entitled to be recognised as refugees may more often than not arrive at a port of entry without the necessary documentations and be placed in inadmissible facility (Lawyers for Human Rights (supra) para 20). Such persons have a right to apply for refugee status, and it is unlawful to refuse their entry if they are bona fide in seeking refuge (para 22; Bula \& Others (supra) para 75). There is a duty on the Department's officials to ensure that intending applicants are given every reasonable opportunity to file an application with the relevant Refugee Reception Office. However, this does not apply to individuals who are excluded from refugee status by section 4 of the Refugees Act (para 22; Bula \& Others (supra) para 76). A person does not qualify for refugee status if there is reason to believe that he or 
she (a) had committed a crime against peace, a war crime or a crime against humanity, as defined in any international legal instrument dealing with any such crimes; or (b) has committed a crime which is not of a political nature and which, if committed in the RSA, would be punishable by imprisonment; (c) has been guilty of acts contrary to the objects and principles of the United Nations Organisation or the Organisation of African Unity; (d) enjoys the protection of any other country in which he or she has taken residence (Refugees Act 130 of 1998, section 4).

The provisions of the Refugees Act are also in accordance with international law and practice, as evidenced by the decision of the European Court of Human Rights in Amuur v France (1996) 23 EHRR 533 and Riad and Idiab v Belgium No 29787/03. In both cases, the court had no difficult in holding that that municipal courts had jurisdiction to deal with the rights of persons held in circumstances similar to those of the appellants (para 24; Bula \& Others (supra) para 71).

The appellants would face a real risk of suffering physical harm if they were forced to return to Somalia. It is common knowledge that Somalia is a dysfunctional state and lacks a central or effective government to protect its citizens. Therefore, there is no effective guarantee that appellants would not be persecuted or subjected to some forms of torture, or cruel, inhuman and degrading treatment if they were compelled to go back to Somalia. Refugees Act seeks to address the prevention of this harm by preventing a refugee's deportation. Deportation to another state that would result in the imposition of a cruel, unusual or degrading punishment is in conflict with the fundamental values of the constitution (para 26, see also Mohamed and Another v President of the Republic of South Africa and Others (Society for the Abolition of the Death Penalty in South Africa and Another intervening) 20013 SA 893 (CC), 20017 BCLR 685 (CC), paras 48,52 and 54 ). The principle of non-refoulement that prescribes that no refugee should be returned to any country where he or she is likely to face persecution or torture has a significant importance (GM Ferreir \& MP Ferreira-Snyman "Die beginsel van non-refoulement as grandslag van die vlugtelingereg" (2004) 2 TSAR 343, 345; WH Olivier "The new asylum law in South Africa" (2002) 4 TSAR 650, 666 - 667; F Jenkins "Coming to South Africa: an overview of the application for asylum and an introduction to Refugees Act" (1999) 24 SAYIL 182, 187 - 188; Kubuika and Another v Minister of Home Affairs and Others 19974 SA 341 (C) 343 E-G; Chahal v United Kingdom (1997) EHRR 413, para 107; Goodwin - Gill The refugee in international law (1996) 117; A Aust Handbook of international law $2^{\text {nd }}$ ed. (2010) 176-7; A Katz "Refugees" in J Dugard International law a South African perspective $4^{\text {th }}$ ed. (2011) 352).

Bertelsmann AJA stated that 'refusing a refugee entry to this country, and thereby exposing her or him to the risk of persecution or physical violence in his/her home country is in conflict with the fundamental values of the constitution' (para 27). Potential asylum seekers and refugees held in inadmissible facility are entitled to the assistance of the Department of Home Affairs' officials and need show no more than that they are persons who might qualify as refugees or asylum seekers (para 28). This applies to individuals or persons regardless of whether they have been previously admitted in South Africa as refugees or asylum seekers.

\subsection{Sovereignty of the state}

A sovereign state has exclusive control over its territory. Foreign states may exercise only such authority in its domain as may be agreed by international treaty (para 29). Dugard states that statehood is defined by a permanent population, a defined territory, government and capacity to enter into relations with other states. He adds that in order to meet this requirement, a state must have a government that is in effective control of its territory, and that is independent of any other authority (Para 29, Dugard International Law - A South African Perspective 3ed (2005) 82; Commissioner of Taxes; Federation of Rhodesia v McFarland 19651 SA 470 (W), 473G - 474A, 19651 All SA 389 (W); S v Banda and Others 19894 SA 519 (BG)).

As South Africa is clearly a sovereign and independent state, the appellants are within it and entitled to the protection of its laws, even if they happened to have arrived in the course of being deported from another sovereign and independent state (para 29). So, the refugees are the responsibility of the Department of Home Affairs and it has a duty to admit them in the RSA. The court, through Bertelsmann AJA, stated that the appellants did not intend to abandon their respective refugee and asylum seeker status, and upheld their appeal with costs (paras 32 and 33).

\subsection{Punitive costs for officials intentionally disregarding their duties}

Section 7 of the Constitution imposes the duty on organs of state -and thus on officials of the Department of Home Affairs- to respect, promote and fulfil the rights in the Bill of Rights. The court found that the respondents' officials had failed to comply with these demands. In the manner they dealt with the appellants, they had little regard to their fears for their safety if they were compelled to return to Somalia (para 33). Furthermore, the respondents failed to inform the court 
immediately of the fact that the appellants' files had been traced on the Department's records (para 35). They insisted that they did not have any record of the appellants in their disposal.

Bertelsmann AJA noticed that South African courts have on several occasions expressed their disquiet at the failure of Government officials, including the Department of Home Affairs' officials, to respect the rights of individuals they deal with and to act in accordance with their duties imposed by the Constitution. (Para 36, see also Eleveth $v$ Minister of Home Affairs and Another 200411 BCLR 1223 (T), para 45 - 48; Nyathi v MEC for Gauteng Department of Health and Another 20085 SA 94 (CC), 20084 BCLR 865 (CC); Total Computer Services (Pty) Ltd v Municipal Mayor, Potchefstroom Local Municipality and Others 20084 SA 346 (T), para 21, 2007 JOL 20884 (T); Van Straaten v President of the Republic of South Africa and Others 20093 SA 457 (CC), 20045 BCLR 480 (CC)). The court found that the respondents' officials failed to understand the very objet and purpose of the Refugees Act it was their duty to apply. As a result, they had caused unnecessary litigation and wasted costs. The court stated that if the appellants had given timeous notice of an intention to apply for a punitive costs order, they would have been granted in all likelihood (para 36).

It is submitted that punitive costs should be granted if the officials have intentionally disregarded their duties causing great hardship, unnecessary litigations and costs. This will encourage government officials to perform their duties to the best of their ability and knowledge. It will also reduce hardship to the people who are dealing with government officials. Punitive costs order must follow the suit regardless of whether parties to the litigation have applied for such an order. It is submitted that such an award is necessary in order to vindicate the fundamental right that has been infringed and to serve as a deterrent against future infringements of these rights by organs of state.

\section{Conclusion}

The Abdi case has created a precedent that deportees in inadmissible facility have a right to apply for asylum in the RSA. They are located in an area that is under the sovereignty of the RSA. Thus, the Bill of Rights, international conventions and municipal laws governing refugees apply to such persons. Once there is an indication to apply for asylum, the Home Affairs' officials have a duty to assist the concerned person to file such an application at a Refugee Reception Office.

Government officials must intend to perform their duties or tasks as provided by the Constitution and other statutes. They should be ordered to pay punitive costs if they intentionally fail to perform their tasks and cause hardship to the individuals who expected their assistance. The punitive costs should follow even if the parties did not apply for such orders.

This judgment is consistent with the repetitive findings of our courts that excessive use of immigration detention by Home Affairs is unlawful, unconstitutional and a violation of our international obligations. The judgment in the Abdi case is, in the authors' view, correct and gives effect to fundamental principles of the constitution, refugee laws and international law.

\section{References}

\section{South African statutes}

Civil Aviation Act 13 of 2009

Constitution of the Republic of South Africa, 1996

Immigration Act 13 of 2002

Promotion of Administrative Justice Act 3 of 2000

Refugees Act 130 of 1998

\section{Regulations}

Regulations in terms of section 38 of Refugees Act 130 of 1998, Government Gazette 21075 (6 April 2000)

\section{South African cases}

Abdi and Another v Minister of Home Affairs and Others 20113 SA 37 (SCA), 20115 BCLR 529, 20113 All SA 117 (SCA)

Bula \& Others v Minister of Home Affairs \& Others 20124 SA 560 (SCA), (589/11) [2011] ZASCA 209

Commissioner of Taxes, Federation of Rhodesia v McFarland 19651 SA 470 (W), 19651 All SA 389 (W)

Eleveth v Minister of Home Affairs and Another 200411 BCLR 1223 (T)

Kubuika and Another v Minister of Home Affairs and Others 19974 SA 341 (C) 
Lawyers for Human Rights and Another v Minister of Home Affairs and Another 20044 SA 125 (CC), 20077 BCLR 775 (CC)

Mohamed and Another v President of the Republic of South Africa and Others (Society for the Abolition of the Death Penalty in South Africa and Another intervening) 20013 SA 893 (CC), 20017 BCLR 685 (CC)

Nkondo v Minister of Police and Another 19802 SA 894 (O), 19804 All SA 67 (O)

Nyathi v MEC for Gauteng Department of Health and Another 20085 SA 94 (CC), 20084 BCLR 865 (CC)

S v Banda and Others 19894 SA 519 (BG)

Total Computer Services (Pty) Ltd v Municipal Mayor, Potchefstroom Local Municipality and Others 20084 SA 346 (T)

Van Straaten v President of the Republic of South Africa and Others 20093 SA 457 (CC), 20045 BCLR 480 (CC)

\section{European Court of Human Rights cases}

Amuur v France (1996) 23 EHRR 533

Chahal v United Kingdom (1997) EHRR 413

Riad and Idiab v Belgium No 29787/03

\section{International Conventions}

Chicago Convention on International Civil Aviation (1944)

Convention Governing the Specific Aspects of Refugee Problems in Africa, 1969

Convention Relating to the Status of Refugees, 1951

Protocol Relating to the Status of Refugees, 1967

\section{Journal articles}

Ferreir, GM \& MP Ferreira-Snyman 'Die beginsel van non-refoulement as grandslag van die vlugtelingereg' (2004) 2 TSAR 343

Jenkins, F "Coming to South Africa: an overview of the application for asylum and an introduction to Refugees Act" (1999) 24 SAYIL 182 Olivier, WH 'The new asylum law in South Africa' (2002) 4 TSAR 650

\section{Books}

Aust, A Handbook of international law 2nd ed. (2010)

Dugard, J International Law - A South African Perspective 3ed (2005)

Gill, G The refugee in international law (1996)

Katz, A "Refugees" in Dugard J International law a South African perspective 4th ed. (2011) 